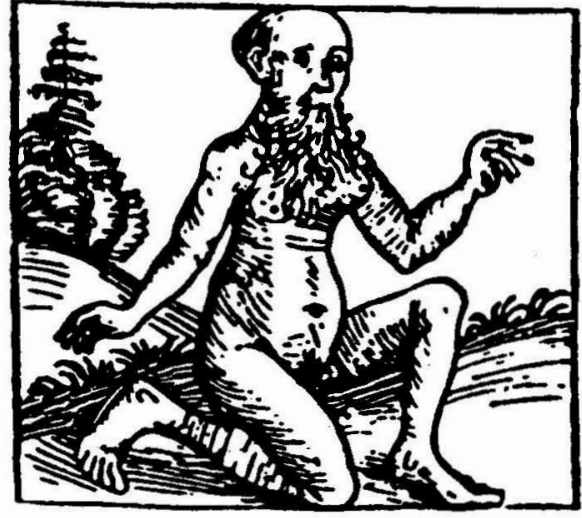

Hermafrodit

\section{Et bibliotek pakkes ud}

Om bogsamleri og Walter Benjamin

GitTe BROENG KRISTENSEN

VII. Bücher und Dirnen - selten sieht einer ihr Ende, der sie besass. Sie pflegen $\mathrm{zu}$ verschwinden, bevor sie vergehen.

Walter Benjamin, Einbahnstrasse.

For nogen tid siden fik jeg lov at låne en bog af en ven, som er bibliofil. Det var en samling af digteren Paul Celans prosatekster, heriblandt hans taler. Bogen så ud til at være ganske ny, og skulle tilsyneladende blive ved med det, så jeg fik den udleveret i en beskyttende plasticpose med strenge instrukser om ikke at knække den i ryggen. Omslaget var i en stiv kvalitet, og jeg kunne knap åbne bogen, men måtte læse ned i den smalle kløft mellem siderne, hvor de dybestliggende ord blev næsten usynlige. Det var naturligvis en noget anstrengende læseproces og netop af den grund, forekommer det mig, satte jeg større pris på det, der blev lokket frem af de skrånende sider. Der var noget særligt over denne bog, som skulle behandles andægtigt; og da jeg omsider var færdig med den, fandt jeg pligttro en plasticpose frem, som den blev returneret $i$. Senere påstod min ven iøvrigt, at jeg havde knækket ryggen på bogen, men for mig var det en oplevelse af stor fromhed alligevel, for jeg havde aldrig før været så varsom med en bog. 
Mens jeg sad med eksemplaret i hænderne og skulle passe på, havde jeg glimtvis følt en ømhed over for bogen, som ikke kunne spores tilbage til Paul Celan, men mere havde at gøre med bogen som en ting, og det undrede mig. På et tidspunkt besluttede jeg derfor at opsøge min bibliofile ven for at få mere at vide om denne liaison, som kun havde mærket mig med en lille gnist, men vakt min nysgerrighed. Han var imidlertid ikke begejstret for min udspørgen, og viste mig ironisk nok tilbage til bøgernes sfære, til en tekst af Walter Benjamin Ich packe meine Bibliothek aus med undertitlen Eine Rede über das Sammeln (1931). Og det skulle så alligevel lykkes mig at få en bibliofil i tale.

\section{En støvers lyst}

Man træffer Walter Benjamin i et kaos af opbrudte kasser, støv og bøger naturligvis. Flere tusinde hengemte bind er han i færd med at pakke ud efter to års adskillelse, og tilfredsheden med den længe ventede handling lyser allerede ud af hans indledende ord: „Ich packe meine Bibliothek aus. Ja." Det sidste lille ord er lukket inde af to punktummer, så man ikke uden videre kan forcere det, men må dvæle ved den positive bekræftelse; og den dybe a-lyd i "Ja" er næsten som en udånding, hvor ens skuldre sænkes, og markerer et veltilfredst ophold i fyldeordet, inden der fortsættes.

Det lille "Lesestücke" er udformet som en tale over bogsamleri, og anledningen er selvfølgelig udpakningen, som ikke bare er en hurtigt afspillet ouverture. I løbet af teksten vender Benjamin tilbage til den som i et musikstykke, hvor et tema gentages med variationer, for hver gang er de tømte kassers antal blevet større og tidspunktet på døgnet blevet senere. Udpakningen skaber på den måde en fremadskridende handling i teksten samtidig med, at den udgør den scene hvorfra „fortælleren" Benjamin taler. Teksten deler således nogle træk med den fiktive tekst uden at være en sådan, med den effekt, at der etableres et rum og en stemning, som er befordrende for det billede, Benjamin ønsker at give af samleren og bogsamleriet.

Næsten enhver udpakning er forbundet med spænding, fordi noget man engang har gemt væk eller noget hemmeligt vil af- sløre sig for en bag indpakningen, og det forekommer mig at være den enkleste suspense-effekt i verden. Det er netop følelsen af spænding, som Benjamin opfordrer sine tilhørere til at dele med sig, mens han pakker ud og total uorden hersker omkring ham; for det er hvad han føler i denne stemning af opløsning.

Erindringen er ifølge Benjamin et vigtigt motiv for samleren, og udpakningen er netop et billede på erindringens bevægelse, hvor der rodes op i nedpakkede lag, og det der længe har været gemt væk ser dagens lys igen. Benjamin kommer således til at tænke på de geografiske steder, som anskaffelsen af bøgerne er knyttet til, og på de oplevelser han har haft i den forbindelse, og fascinationen ved dette gensyn med fortiden er så stor, at han ikke har lyst til at stoppe udpakningen. Den uordentlige scene er også et overbevisende argument imod systematiske opremsninger af hans biblioteks bestand, og talens motiv er da heller ikke at give et indblik i en samling men i samlerens forhold til bogerne, ja, i selve samleriets væsen. Benjamin vælger dermed en analytisk tilgang, som er forskellig fra den gængse, mere deskriptive, litteratur om bibliofili. Omvendt hersker der ingen tvivl om at Ich packe meine Bibliothek aus heller ikke er en videnskabelig tekst, dertil er formen for ecxcentrisk og tonen for personlig.

Talen, som genre, knytter an til en situation, og indbyder til en lettere tone samtidig med at subjektiviteten understreges, fordi man henfører ordene til en personlig røst. Men Benjamin betoner yderligere sin subjektivitet ved at gøre opmærksom på, at han $\mathrm{i}$ det store og hele kun taler for sig selv. Alligevel undgår han ikke helt en normativ tone med en formulering som "für den wahren Sammler" / "for den sande samler" som han bruger flere gange, hvilket må betyde, at der også findes forkerte samlere; og skurken er "Interessanten”, der samler på bibliofile nytryk. I en almindelig ordbog udredes ordet bibliofil således: „(af græsk biblíon bog, og phílos ven) bogelsker; samler af smukke ell. sjældne bøger." Der er i den definition ingen skurke, men for en samler som Benjamin, der vil „Die alte Welt erneuern” / „Forny den gamle verden" har den luksuriøse smag ingen interesse. Walter Benjamin er hovedpersonen i denne lille tekst om biblio- 
teker og deres lidenskabelige herrer, som i princippet lige så godt kunne være damer - der er bare ikke mange af dem. Og måske er der brug for en genopfriskning: Det hele startede med en bog, som knap måtte åbnes.

\section{Skæbnetyder}

„Det er jo ikke det ydre det kommer an på" siger man ofte, når snakken falder på en persons tiltrækningskraft, navnlig når vedkommende ikke indlysende har en sådan. Der er noget besindigt over frasen, som ikke harmonerer med lidenskabelighed, for når man forelsker sig, er det ikke i første omgang sjælens dybder, man ser og fanges af men den begæredes udstråling og udseende. En bogelsker har det tilsyneladende lidt som den forelskede, når det drejer sig om at vurdere en bog, og skulle man karakterisere forskellen mellem den bogligt interesserede (ikke at forveksle med Interessanten) og bogelskeren, ville det ikke være uhørt at tale om en modsætning mellem fornuft og følelse.

Fornuft har at gøre med evnen til at fornemme, at opfatte, og relaterer sig til intellektet; og den bogligt interesserede, som i dikotomien naturligvis er fornuftens repræsentant, vurderer bogen på dens indhold. Bogelskeren er på sin side en mere sværmerisk natur, som drives af følelsen. Grundbetydningen af føle er „undersøge ved berøring", og derved impliceres noget legemligt, noget man mærker ved berøring. Benjamin beskriver i Ich packe meine Bibliothek aus en oplevelse, der passer fint på dette folelsessignalement, og forhistorien er den, at han er faldet for en auktionsvare, en smuk udgave af Balzacs Peau de Chagrin fra 1838, der ud over auktionsnummeret også viser sig at være forsynet med den oprindelige etiket fra papirhandlen, hvorfra den i sin tid blev solgt for første gang. Det vækker en længsel i ham efter den "schöne Zeit" hvor man, selv i en papirhandel, kunne købe sådanne pragtværker.

„Ich war zur Vorbesichtigung zu Emil Hirsch gekommen, hatte mir 40 oder 50 Bände durch die Hand gehen lassen, diesen aber mit den glühenden Wunsch, ihn nie mehr aus ihr geben zu müssen.“ / „Jeg var kommet til forbesigtigelsen hos Emil Hirsch, og havde prøvende taget 40 eller 50 bind op $\mathrm{i}$ hånden, men dette ene, med det brændende ønske aldrig mere at skulle give slip på det igen." Hans lyst til at erhverve sig bogen kædes ikke alene sammen med berøringen af den, men også med resultatet af hans "undersøgelse“, nemlig opdagelsen af etiketten, det livskraftige spor fra den "schöne Zeit", som bogen stammer fra. Og samhørigheden han mærker med dette bind, får det håndgribelige udtryk, at han ikke ønsker at slippe bogen igen. Bibliofili knytter sig således på én gang til noget meget konkret og noget næsten uforklarligt.

I Den store danske Encyklopædi defineres bibliofili som „Sansen for at værdsætte bøger i gode eksemplarer, bibliofili opstår i princippet når glæden over bøgers indhold udvides til også at gælde deres fysiske fremtrædelse." Men man kunne skærpe definitionen ved at sige, at bibliofili for alvor kan konstateres, når man afviser at modtage en bog gratis, som man ovenikøbet holder af, fordi eksemplaret i ens øine ikke er attraktivt; det er dog ikke ensbetydende med, at bibliofiles samlinger udelukkende består af værdifulde og uopdrivelige værker, selvom de måtte ønske sig det. Langt de fleste bibliofile går efter førsteudgaver, nogle efter Exlibris (bogejermærker), smukke indbindinger eller illustrationer. Eksemplarer der er mærket af skæbnen på en særlig heldig måde er også eftertragtede, og der kan være tale om forfatterdedikationer eller en berømtheds signatur som eksempelvis Søren Kierkegaards. En af de få bøger Kierkegaard skrev sit navn i var førsteudgaven af Christian Winthers Haandtegninger fra 1840 i miniature-format. Han gik ofte med den i sin frakkes inderlomme, og den må derfor have været med på flere af hans spadsereture rundt i København. Bogen har siden hen passeret Atlanten, og er nu i Minnesota U.S.A. ${ }^{1}$ hvor man sikkert skal have flere frakker på for at kunne spadsere sig en tur i de iskolde vintre; og det at den findes der, er ikke Christian Winthers bedrift men den herres, som bar den rundt i Københavns gader.

\section{Børnebøger og tatoveringer}

Walter Benjamin kalder samleren for „Physiognomiker der Dingwelt" / "Tingsverdenens fysiognomiker“. Ordet "fysiognomiker" er en personificering af fysiognomik, som bygger på forestil- 
lingen om, at man af et menneskes ydre kan drage slutninger om dets sjælelige ejendommeligheder, specielt dets karakter. „Fysiognomikeren" er altså en person, der har helliget sig det ganske uvidenskabelige studium af fysiognomik: at se det indre i det ydre. Noget der er værd at bemærke er, at fysiognomik er en lære, der knytter sig til mennesket, og når Benjamin overfører den på bøgerne viser det, at han betragter dem som besjælede ting. Uden at ville fornærme nogen, kan man sige, at børn heller ikke skelner væsentligt mellem døde ting og levende væsener. De kan have et kærligt forhold til en bamse eller en dukke, give den et navn, snakke med den, sove med den osv. På samme måde synes tingene at leve for en samler, selvfølgelig forstår han at skelne, men han føler tilsyneladende en samhørighed med dem, som er mere udpræget end hos andre voksne mennesker.

Den særlige tillid til tingene illustreres også i Benjamins morsomme forfatter-definition, som går ud på, at forfattere er folk, der simpelthen ikke er tilfredse med de bøger som findes, og derfor skriver selv. I en sådan betragtning kommer skabertrangen reelt ikke indefra men udefra, fra bøgerne, som ikke behager den potentielle forfatter, og sat lidt på spidsen skaber bøgerne således bøger. Forestillingen om at ting afføder nye ting ses også i den forbindelse, han etablerer mellem de samlealbum med papirsmærker, som han arvede fra sin mor, og hans børnebogssamling: „Sie sind die Samen einer Sammlung von Kinderbüchern, die noch heute ständig fortwächst, wenn auch nicht mehr in meinem Garten.“ / „De er spiren til en samling af børnebøger, som den dag i dag stadig vokser, også selvom det ikke længere er i min have." Den botaniske symbolik illustrerer tanken om at tingene gror, og at de gør det upåagtet, hvis jord det er i. Billedet er således også en hentydning til den nylige skilsmisse fra hans kone Dora og børnebogssamlingen, som han betragtede som hendes ejendom. Af den grund er den i dag den eneste samling i Benjamins bibliotek, som eksisterer. Det øvrige, heriblandt fine samlinger af tysk og fransk litteratur, blev opløst ved hans flugt fra nazisterne og senere død ved grænsen til Spanien i 1940. Børnebogssamlingen bestod af gamle børnebøger, fortrinsvis tyske, og mange af dem i førsteudgave med flotte illustrationer. Dora og sønnen Stefan emigrerede efter skilsmissen til Syd-Frankrig, men flygtede i 1939 til London og børnebogssamlingen fulgte med. Efter Stefan Benjamins død vendte samlingen i 1985 tilbage til Tyskland. (Das Institut für Jugendbuchforschung in Frankfurt am Main). Samlingen er på den måde blevet kastet omkring i verden som Kierkegaard-eksemplaret.

Walter Benjamin opholdte sig i flere omgange hos Bertolt Brecht i Skovbostrand ved Svendborg. I forbindelse med et af disse ophold var han i hovedstaden, men måtte desværre ligge i sengen en stor del af tiden; rejsen har dog ikke været helt forgæves, og til vennen Gerschom Scholem skriver han: „Immerhin habe ich in Kopenhagen das Etablissement eines Tätowierkünstlers entdeckt“ / „Immervæk har jeg opdaget et tatovør-etablissement i København." Grunden til hans besøg hos den københavnske tatovør er den, at han efter afskeden med børnebogssamlingen i stedet begyndte at samle på billedark med tatoveringer, og han har tilsyneladende erhvervet sig nogle fine af slagsen. Opdagelsen af tatovør-etablissementet har ihvertfald gjort indtryk, for det er den eneste oplevelse i byen han fortæller om i brevet, og det siger noget om samleren som turist.

Benjamin havde altså fundet en substitut for børnebøgerne med de fine illustrationer i tato-billederne, og umiddelbart ligger de to ting hinanden fjernt; men selvom sidstnævnte traditionelt ikke forbindes med "Guds bedste børn", er der tale om billeder, ligesom børnebøgerne havde deres. Det virkelig interessante som afslører sig i denne ersatz er imidlertid et regulært behov for at samle, og Benjamin var en decideret samlernatur. Bibliofili synes med andre ord ikke at komme ud af intet - en stor amerikansk bogsamler, W.S. Lewis, startede efter sigende med fluer i fem-årsalderen, og opbyggede siden hen verdens største samling af Walpoliana, værker af og med relation til den engelske forfatter Horace Walpole (1717-97).

\section{Redderen}

Benjamin pakker sit bibliotek ud men før eller siden skal bøgerne placeres på de tomme hylder, og omkranses af „die Leise Langweile der Ordnung“ / „ordenens lette kedsommelighed“, som 
han udtrykker det. Men den bibliofile behøver ikke nødvendigvis, i modsætning til de offentlige biblioteker, at tænke i brugervenlighed, når han indretter sit bibliotek. Han kan strengt taget gøre som han vil, når blot han har styr på hvilke bind det indeholder, og selv det findes der råd for. Der kan således udarbejdes bibliografier, kataloger og kartoteker over bestanden af bøger, men når man op på nogle tusinde bind, er det nok hensigtsmæssigt at operere med en nogenlunde let gennemskuelig orden på hylderne, medmindre man har tiden for sig.

Den lukkede bog lader sig forholdvis nemt kategorisere og klassificere; siderne er samlede, og på bogens rette ryg står forfatternavn og titel og byder sig til over for ordensmagten. Bogen kan umiddelbart kombineres med andre bøger, som den har en fællesnævner med, og det styrende princip vil oftest være alfabetet eller emnet. Den åbne bog, derimod, er i princippet en opløsning af den samlende orden. Den vender helt naturligt ryggen væk fra en, og man ser i stedet ned i et hav af ord, og møder en mangfoldighed af betydninger, hvis bogen er tilpas kompleks, som gør at den i reglen ikke er til at blive helt færdig med, og set i det perspektiv forekommer en oversigts-skabende klassifikation at være intetsigende. Så opløsningen af bibliotekets orden truer selv i dets enkelte komponenter.

Walter Benjamin skulle efter sigende have hyldet et ganske særligt demokrati i sine reoler. Ifølge vennen Scholem arrangerede han sit bibliotek i forskellige bizarre mønstre, hvor de store værker, som betød meget for ham, stod side om side med helt perifære ting. Måske har han forsøgt at modarbejde hyldernes lineære orden for at bevare den spænding, som han forbandt med udpakningens opløsning, men hvorfor disse rariteter? I Ich packe meine Bibliothek aus beskriver Benjamin, hvorledes han har hjemført bøger, som han aldrig havde skænket en tanke, fordi de lå prisgivet og forladte hen på det offentlige marked, og han sammenligner sin bedrift med prinsen i et af Tusind og een nats eventyr, der købte en skøn slavinde fri for at give hende hendes frihed. Hans sammenligning med prinsen viser, at han ser noget heltemodigt i sin gerning: At han redder de "trælbundne“ bøger fra glemsel.
Jeg havde en lignende oplevelse på hovedbiblioteket, hvor jeg ville finde bøger om bibliofili, og søgte i det moderne biblioteks kartotek: Databasen. Efter endt søgning måtte jeg konstatere at hovedparten af bøger, der handlede om det at elske bøger, ikke længere var at finde i selve biblioteket, men nu befandt sig i magasinet $i$ kælderen. Jeg henvendte mig derfor til bibliotekaren for at få ham til at finde dem til mig dernede i undergrunden. Efter en rum tid kom han tilbage med en stak, alle forsynet med runde, orange klistermærker, som en slags advarselsmærker: „Denne bog er der ikke mange mennesker, som gider læse!" Men jeg var glad ved synet, for jeg havde brug for dem. Den lettere forpustede bibliotekar sagde så til mig: „Du har netop reddet disse bøger fra at blive kasseret, for jeg kan se, at de ikke har været udlånt $i 3$ år. Jeg er ved at føre protokol over hvilke bøger, der falder for den tidsfrist, men nu får de så en ny tre-års-periode." Der kommer hele tiden nye bøger til på markedet, som fortrænger de gamle, som ingen længere fatter interesse for, men en samler som Benjamin holder forbindelsen ved lige til fortiden via fragmenterne af den, som aktualiseres $i$ hans samling.

Et privat bibliotek udtrykker naturligvis noget om den person, som har samlet det, fordi det er præget af den særlige blanding af interesseområder vedkommende har haft. Således udtrykker Benjamins særlige arrangement af sit bibliotek, ifølge Susan Sontag:"strategien i hans værk, hvor det surrealistisk inspirerede blik for de skatte af betydning der lå i det efemeriske, det upåagtede og det forsømte arbejdede side om side med hans loyalitet over for den lærde smags traditionelle kanon." Så de "reddede" rariteter har ikke ikke blot været mønsterfremkaldende levn. Det der gør enhver samling unik, er den præcise sammensætning af eksemplarer inden for de forskellige interessefelter, og den er således et udtryk for, hvad det er lykkedes samleren at finde rundt omkring $i$ alverdens boghandlere, antikvariater og på bogauktioner. Ved samlerens død er biblioteket imidlertid ofte blevet opløst igen; det findes der utallige eksempler på i bibliofiliens historie - sikkert næsten lige så mange som det antal samlinger, der har eksisteret. Men opløsningen er paradoksalt nok forudsætningen for, at nye samlinger kan opstå, og 
auktioner og antikvariater har fungeret som sådanne „omfordelingssteder “" hvor bøgerne har fået nye ejere, og en plads i en anderledes kombination end den de sidst indgik i - måske i et andet land.

\section{Amourøse erobringstogter}

Benjamins liv passerer revue mens han pakker ud. Han tænker på „Riga, Neapel, München, Danzig, Moskva, Firenze, Basel, Paris" - de byer hvor han har fundet så mange bøger. Og på steder hvor han har boet med sine bøger. Udpakningen får erindringerne til at vælde op, og som man kan se, er der en nær relation mellem lidenskaben til bøgerne og hans mange rejser. Walter Benjamins finansielle situation var ringe, primært fordi han ikke fik ansættelse ved noget universitet, og i stedet måtte ernære sig ved en ikke særlig indbringende skribentvirksomhed. Men alligevel rejste han utrolig meget, og af hans breve fremgår det, at han indimellem har solgt ud af sine bøger, ganske vist ikke sine dyrebareste, for at finansiere udlandsopholdene; og i forbindelse med disse har han så hjemført nye bøger. Der har altså eksisteret en ganske særlig økonomi mellem de to vigtige elementer i hans liv. Susan Sontag skriver om denne forbindelse: "Jagten på bøger bidrager ligesom den seksuelle jagt til nydelsens geografi - en anden grund til at strejfe om i verden."

I Ich packe meine Bibliothek aus er der en sekvens, hvor Benjamin beskriver sine indtog i byerne og erobringen af bøgerne ved hjælp af en komplet militærmetaforik.

„Sammler sind Menschen mit taktischem Instinkt; ihrer Erfahrung nach kann, wenn sie eine fremde Stadt erobern, der kleinste Antiquitätenladen ein Fort, das entlegenste Papiergeschäft eine Schlüsselstellung bedeuten. Wie viele Städte haben sich mir nicht in den Märchen erschlossen, mit denen ich auf Eroberung von Büchern ausging." / "Samlere er mennesker med taktisk instinkt; når de erobrer en fremmed by kan det mindste antikvariat, via deres erfaring, vise sig at være et fort, og den mest fjerntliggende papirhandel betyde en nøglestilling. Hvor mange byer har ikke åbnet sig for mig, når jeg marcherede ud på bogerobring."
I Benjamins forestillingsverden og vokabular transformeres byen til en slagmark, som hans en-mands-hær marcherer ind i. Marchen har dette taktfaste over sig, næsten noget mekanisk, man følger trop, og den tamburmajor, som fører an i Benjamins hær, er bibliofilien. Han ved altid, ligesom andre bibliofile, hvad han skal foretage sig, når han kommer til en ny by: Ud og finde et "fort" som kan indtages, og kun en uforbederlig forfører lider af en lignende forudsigelighed.

Roland Barthes peger i Kærlighedens forrykte tale, i kapitlet om Henrykkelse på (den etymologiske betydning af henrykke er 'rykke bort'), at sproget eller mere nøjagtigt ordforrådet har paralleliseret kærlighed og krig: ,,i begge tilfælde drejer det sig om at erobre, røve, kapre osv.“ Og indsat i en sådan diskurs er bogen genstanden for den bebrillede, krumryggede, intellektuelles amourøse krigsførelse. Roland Barthes henviser til Sabinerindernes Rov for at illustrere paralleliseringen mellem kærlighed og krig. Ifølge myten inviterede romerne, anført af Romulus, Sabinerne til væddeløbsfest, og røvede midt under festen deres døtre, som så siden hen sørgede for at fædre og mænd sluttede fred. Barthes påpeger, at der i mellemtiden er foregået en mærkværdig krydsdans mellem måden at være aktiv og passiv på, så at henrykkelsen er en følelse, som „røveren“ (det være sig mand eller kvinde) uden at gøre noget vækker i den „røvede“, som på den måde er i den tilbedtes vold. „(Af den arkaiske model er der imidlertid et åbenbart spor tilbage: den forelskede - den røvede, henrykte bliver automatisk femininiseret.)“ Set i dette kærlighedsperspektiv er bogelskere sådanne arkaiske røvere, der ikke blot i ord men også i gerninger erobrer „de skønne Sabinerinder", bøgerne.

\section{Taktik og sporsans}

Taktik er ofte forudsætningen for en vellykket erobring, og den drevne samler er lidt af en Romulus. Der er to auktionshistorier i Ich packe meine Bibliothek aus. I den første møder man den unge Benjamin, der er faldet for eksemplaret af Peau de Chagrin. Alle byderne sidder ved et langt bord, Benjamin over for den berømte samler fra München, Friherre von Simolin, der som en anden general er den, alles blikke samles om, men „krigerne“ er alle 
interesserede i Balzac-værket: „(...) kurz es kam zu einem scharfen Kampf," / "det kom snart til en skarp kamp", og i kampens hede når bogen op $i$ et prisleje, som ingen havde forventet, og det er som om byderne pludselig besinder sig, og lader de dragne sværd falde. Der er noget hektisk over Benjamin - han vil have den bog, og med hjertebanken byder han lidt over prisen med den klare bevidsthed, at han ikke kan konkurrere med de store samlere omkring bordet, så det er nu eller aldrig. Men ingen af de andre reagerer, fordi auktionarius er begyndt at gøre klar til det næste nummer, som også er interessant. Bogen går til den fattige studerende Benjamin for et beløb langt over 3000 RM., men han kan næsten ikke vente: „(...) drei Schlägen - mir schienen sie wie durch eine Ewigkeit voneinander getrennt - zum Zuschlag." / „tre slag - der forekom mig at være en evighed imellem dem - til hammerslaget."

Den ældre Benjamin bemærker tørt, at den følgende formiddags besøg hos pantelåneren ikke længere er en del af historien, og dermed får han både illustreret sin letsindighed og den redigering, som gør at denne auktionsoplevelese stadig står tilbage som den mest spændende - han værner om de gode minder. Men det var den taktiske sans vi kom fra, og den viste den unge Benjamin ikke megen af.

Den anden auktionshistorie viser en ældre og mere erfaren herre. Denne gang er det begærede værk Fragmente aus dem Nachlass eines jungen Physikers af Johan Wilhelm Ritter, en meget sjælden udgave. I løbet af auktionen registrerer Benjamin, at der blandt de andre bydere er en kamplysten herre, som hele tiden byder på de samme numre som han, og han er så småt ved at opgive håbet for den ønskede bog, da han pludselig får en "Erleuchtung", der siger ham, at han slet ikke skal byde på bogen. Hans skinmanøvre virker, og modstanderen viser ingen interesse for den virkelige skat, så bogen går tilbage, og det taktiske spil vækker associationer i retning af Kierkegaards, Johannes Forforeren, og hans ord: „Naar man blot veed at overraske, har man altid vundet Spil." - Benjamin holder ud, venter nogle dage, og finder bogen $i$ auktionsforretningens antikvariat, hvor han gør en god handel på grund af den tilsyneladende manglende interesse. Ved hjælp af taktisk sans og tålmodighed lykkes det ham altså at erhverve sig bogen på en, økonomisk set, fordelagtig måde.

Men han kalder den taktisk prægede begivenhed for „das Negativ einer Auktion" / "en auktions negativ“. På et fotografisk negativ er originalens lyse partier som bekendt mørke og omvendt, og det er i grunden også sådan det forholder med de to auktionshistorier. Den første (originalen) er intens, bogen er eftertragtet, og det kommer til kamp. Benjamin tænker ikke på prisen, men lader sig styre af sit begær efter bogen, og får den på sidste bud. „Das Negativ“ / "negativet" er som sagt modsat af positivet, og her er bogen ikke virkelig eftertragtet, men for hans konkurrent kun årsag til spil. For en samler som Benjamin er det positivt når der er rift om en gammel bog, fordi en sådan interesse er et udtryk for en styrkelse af forbindelsen til fortiden, men rent økonomisk har negativet også sine fortrin.

I forbindelse med køb af bøger via kataloger taler han om en særlig sporsans, der har en intuitiv karakter. Et godt køb har således ikke kun at gøre med de midler den bibliofile har til sin rådighed og hans sagkundskab, men med en særlig kontemplativ evne til, ud fra katalogets oplysninger om bogen, at mærke „ob so ein Buch zu ihm gehört oder nicht." / "om en sådan bog hører til hos ham eller ej."

Den amerikanske samler Lewis skulle efter sigende have haft en særdeles udsøgt sporsans, og hans mystiske evne til at finde bøger af Walpole, eller med relation til ham, kan følgende beretning illustrere. Lewis er i London, og drikker te hos en bekendt $i$ et værelse fyldt med reoler, og i den ene ende af værelset er et skab med nogle krukker ovenpå placeret foran en reol: „Uden at tænke over, hvad jeg gjorde ... rejste jeg mig, gik hen over gulvet, fjernede krukkerne, rykkede det tunge møbel væk fra reolen, stak hånden ned bagved og tog en bog frem, som havde tilhørt Walpole. Min vært blev bleg. - Jeg har hørt, at De kunne den slags, sagde han, men jeg troede ikke på det. I tre uger lige siden jeg hørte, De var i London, har jeg prøvet at finde den bog." Lewis fortæller i en dramatisk tone og med stor indlevelse om begivenheden. 
En vigtig faktor i samleriet er således at sætte ord på det man gør, at fortælle erobringshistorien for andre, og det er ikke alene fordi lidenskaben optager en meget, men også af den grund, at det er som at opleve situationen igen - man smager atter lidt af spændingen og glæden ved begivenheden. Benjamins breve er prægede af mange sådanne beskrivelser, dog ikke så detaljerede som Lewis', men fortællelysten er til stede. Et eksempel blandt mange er hentet fra et brev til vennen Ernst Schoen: „Gelegentlich will ich Ihnen wenn es Sie nicht langweilt mehr hiervon, von meinen letzten Erwerbungen schreiben. Ich erzähle so gern davon." / "Af og til vil jeg, hvis det ikke keder Dem, skrive mere herom, om mine sidste erhvervelser. Jeg fortæller så gerne derom." Fortælletrangen kunne godt forveksles med praleri af samme skuffe, som den, visse ublu typer udi elskovslivet leverer, fordi den fremstiller den potente bogelsker, og hans særlige intuitive evne til at støve bøger op på de mærkeligste steder.

For nogle bibliofile tager lidenskaben for bøgerne imidlertid overhånd, og de bliver bibliomaner. Grænsen mellem bibliofili og bibliomani er svær at definere, men et nøgleord er: kontrol. Bibliomanen lyder også navnet: Bognar, hvilket indikerer, at der er tale om en latterlig figur, som lader sit liv styrre af bøgerne - en der ikke har kontrol med sin lidenskab, mens den bibliofile er den potente bogelsker. Et drabeligt eksempel på bibliomani er den tyske prædikant Johan Georg Tinius, der i 1813 blev rovmorder for at finansiere sin passion, der til sidst bestod af et bibliotek med 60.000 bind. Men også den danske samler C.P. Neergaard må siges at have haft et sygeligt forhold til bøgerne: Ved hans død fandt man således bjerge af uopsprættede bøger i hans lejlighed.

Det rituelle, jomfruen og luderen

Et vigtigt aspekt i bibliofilien er de private ritualer som bogsamleren underkaster sine bøger. Hos Benjamin viste ritualiseringen sig $i$ en særlig afventende holdning over for nyerhvervede bøger. Han skriver i et andet brev til Schoen fra 1918 om sine nyerhvervelser: „In einigen Jahren werde ich wissen was einige dieser Werke mir bedeuten, bei manchen wird es vielleicht sehr lange brauchen. Zunächst kommen sie gleichsam in den Weinkeller, werden in der Bibliothek vergraben: ich berühre sie nicht." / "Om nogle år vil jeg vide, hvad nogle af disse værker kommer til at betyde for mig, visse af dem bliver der måske brug for meget længe. Foreløbig kommer de i vinkælderen, bliver begravet i biblioteket: Jeg berører dem ikke." Som den unge vin der skal lagres, før den kan nydes, skal Benjamins bøger først modnes, og falde til i ",den magiske encyklopædi“, som han kalder biblioteket i læsestykket, og den afventende holdning kan skyldes den bibliofiles, ofte impulsive, måde at gøre bogindkøb på.

I Ich packe meine Bibliothek aus angiver Benjamin 1920 som skæringsåret for bibliotekets alvorlige ekspansion, og det forklarer han med, at det fra hans opholdssted i Schweiz så ud til, at inflationen kunne gøre bøger uopdrivelige. Han lavede således sin første store bogbestilling, og erhvervede sig langt flere bøger end han i nær fremtid kunne nå at læse. Biblioteket fik altså karakter af et forrådskammer eller af den føromtalte "Weinkeller". Han mener således, at det er frygten for "Aussterben“ der driver samleren, og som han søger at eliminere i sin jagt efter sjældne bøger. Isolationen som Benjamin påtvang sine nyerhvervede bøger, $\mathrm{i}$ deres overgang fra en tilstand til en anden: fra en offentlig sfære og til bibliotekets privatsfære, kan betragtes som en rituel død, hvilket understøttes i sprogbrugen: bøgerne bliver "begravet" i biblioteket. Inden for religionsforskningen taler man om såkaldte overgangsriter, hvis fælles, globale mønster tydeligst påvises i "primitive" kulturer, hvor man lever i direkte afhængighed af naturen, og hvor nyt liv ikke er nogen selvfølge. Overgangsriterne træder i kraft ved afslutningen af et livsforløb og påbegyndelsen af et nyt, eksempelvis puberteten, for at sikre en tryg passage mellem stadierne: „,den el. de implicerede udskilles fra deres hidtidige sammenhæng, isoleres $i$ en overgangsperiode for endeligt at genoptages og tildeles en ny status under festlige former." Mønsteret følger naturens cyklus: Gennem død opstår nyt liv; og i den vigtige midterste fase, isolationen, illustreres denne sammenhæng rituelt, eksempelvis gennem en symbolsk begravelse, og så er vi tilbage hos Benjamin. I hans bibliotek indvies de nye bøger under deres isolation $i$,den magiske encyklopædi", ligesom det unge 
menneske, i sin udsathed under isolationen, konfronteres med de hellige kræfter, der styrer hans folks liv, og derved indvies i det nye liv som medansvarlig voksen, der venter ham efter genoptagelsen. Bag Benjamins ritual synes derfor også at hvile en forestilling om, at de nye bøger må "dø“ for at "genopstå" som en virkningsfuld del af bibliotekets magiske sammenhæng. Benjamin havde i sit bibliotek en betydelig samling af religionsvidenskabelige værker, så det er ikke usandsynligt at han har modtaget inspiration til den særlige fremgangsmåde her, selvom han bruger vinkælderen som metafor. Det ritualiserede afslører sig også i den måde han omtalte de bøger på, som han ikke ville låne ud. Han kaldte dem: „Tabu“. Derved signaleres der, ud over et forbud, også forestillingen om noget helligt og ukrænkeligt.

Hos mange bibliofile kan man konstatere en slags jomfrudyrkelse, hvilket vil sige at behandlingen af bogen er præget af stor forsigtighed, så dens udseende kan bevares intakt - dog ikke i samme ekstreme grad som hos førnævnte bognar. Det er eksempelvis ikke tilladt at lægge bogen fra sig med ryggen opad, fordi det belaster den unødigt, eller at skrive i bogen - ikke engang ens navn, for det anses ikke for god bibliofil skik. Denne tilbageholdenhed er en kontrast til bogsamleren som „arkaisk røver“, og viser således et skift mellem hans adfærd hjemme i biblioteket, og når han er ude på bogjagt.

Der forekommer at være langt fra lidenskaben for bogen som en ting, og til opfattelsen af den som blot funktion for viden og fornøjelse; men et eksempel på sidstnævnte mere udbredte, og pragmatiske, tankegang finder man, sjovt nok, også hos Walter Benjamin. I hans Einbahnstrasse findes der tretten teser om lighederne mellem bøger og ludere, NR.13, der er præget af en spøgefuld tone, som slåes an i den første tese: "Bücher und Dirnen kann mann ins Bett nehmen.“ / „Bøger og ludere kan man tage med i seng". I sammenligningen med luderen betones bogens "brugsværdi“ eller det man også kunne kalde for bogens „luderlighed“. Det er mange gamle bøgers skæbne at have tilhørt forskellige ejere, men set $i$ et større tidsperspektiv kan man sige, at ingen alligevel har ejet dem - de har kun haft dem til låns, for bøgerne har overlevet dem, og genoptaget deres planløse rotation.
Som et motto for NR.13 har Benjamin valgt nogle vers af digteren Stéphane Mallarmé, der illustrerer bogens overgang fra at være "jomfru“ og til synligt at blive taget i brug ved brevknivens penetrering af de uopsprættede sider. Når først overtagelsen har fundet sted, kan det ikke længere skjules at bogen har tilhørt en, men dens påfaldende lighed med luderen skyldes just, at den er umulig at besidde.

Bibliofili er, med andre ord, en paradoksal lyst, som nærer sig ved bogens "luderlighed“ samtidig med, at bogelskeren i sin lidenskab for bogen forsøger at opholde den i sin forsvinding, ved at indlemme den i sit private bibliotek. Her kan han i fred beundre bøgernes tillokkende ydre, erindre sig hvor i verden han erobrede dem, og hvilken taktik han af og til måtte anvende for at kunne hjemføre dem til sin „magiske encyklopædi“.

\section{Litteratur}

Benjamin, Walter: Ich packe meine Bibliothek aus, 1931, in Angelus Novus, Ausgewählte Schriften 2, 1966.

-Einbahnstrasse, 1969.

-Briefe 1-2, 1966.

Barthes, Roland: Kærlighedens forrykte tale, oversat af Karen Nikolajsen 1985.

Dansten, Esli: Om at være bogsamler, 1979.

Rohde, H.P.: Den rode tråd - boghistoriske studier, 1985.

Sontag, Susan: Under Saturns tegn, oversat af Ib Johansen in Tankestreger - Essays om Walter Benjamin, 1989.

Stefanson, Finn o.a.: Religion / Livsanskuelse, 1983.

\section{Noter}

1. "Kierkegaard Library“, St. Olaf College, Northfield , Minnesota. in Den røde tråd 